\title{
PENINGKATAN KEMAMPUAN PENALARAN MATEMATIS MAHASISWA MELALUI PEMBELAJARAN REFLEKTIF BERBANTUAN APLIKASI MOODLE
}

\author{
Rohana $^{1}$, Yunika Lestaria Ningsih ${ }^{2}$ \\ FKIP, Universitas PGRI Palembang ${ }^{1,2}$ \\ yunikalestari@univpgri-palembang.ac.id
}

\begin{abstract}
ABSTRAK
Tujuan penelitian ini adalah untuk mengetahui peningkatan kemampuan penalaran matematis mahasiswa melalui pembelajaran reflektif berbantuan aplikasi Moodle. Penelitian ini merupakan penelitian deskriptif dengan desain one group pretest-postest design. Subjek dalam penelitian ini adalah 33 orang mahasiswa kelas III.B Program Studi Pendidikan Matematika Universitas PGRI Palembang Tahun Akademik 2017/2018. Data dikumpulkan melalui tes kemampuan awal dan tes kemampuan penalaran matematis. Analisis data dilakukan dengan deskriptif kuantitatif. Hasil penelitian menunjukkan bahwa peningkatan kemampuan penalaran matematis mahasiswa melalui pembelajaran reflektif berbantuan aplikasi Moodle berada dalam kategori sedang.
\end{abstract}

Kata kunci : aplikasi Moodle, kemampuan penalaran matematis, pembelajaran reflektif

\begin{abstract}
This research purpose to investigate the enhancement of students' mathematical reasoning ability through implementation of reflective learning with Moodle application. This research used quasi experimental design with one-group pretest-posttest design. The subject of this study was 33 students of class III.B Mathematics Education of Universitas PGRI Palembang Academic Year 2017/2018. Data were collected through test of initial mathematical ability and test of mathematical reasoning. Data in this study were analyze through descriptive quantitative. The result shown that the enhancement of students' mathematical reasoning who received Reflective Learning model with Moodle application was in the medium category..
\end{abstract}

Keywords : moodle application, reflective learning, students' mathematical reasoning

\section{PENDAHULUAN}

Tujuan pendidikan tinggi yang tertuang dalam Undang-Undang No. 12 tahun 2012 tentang Pendidikan Tinggi antara lain adalah berkembangnya potensi mahasiswa agar menjadi manusia yang beriman kepada Tuhan Yang Maha Esa dan berakhlak mulia, sehat, berilmu, cakap, kreatif, mandiri, menguasai cabang ilmu pegetahuan dan/atau teknologi untuk peningkatan daya saing bangsa. Undangundang tersebut memberikan amanah bahwa pendidikan tinggi merupakan wadah untuk menciptakan manusia yang memiliki kemampuan baik dalam ilmu 
pengetahuan dan/atau teknologi sehingga dapat bersaing menghadapi tantangan zaman.

Lebih lanjut, Suryadi (2012) menegaskan bahwa untuk dapat bersaing secara mandiri dan percaya diri, sumber daya manusia (SDM) harus mampu untuk berpikir secara kritis, logis, sistematis, dan kreatif, yang dikenal dengan kemampuan berpikir matematis. Kemampuan penalaran matematis merupakan salah satu bagian dari kemampuan berpikir matematis yang dituntut untuk dapat dimiliki oleh mahasiswa pendidikan matematika. Dalam National Council of Teachers of Mathematics (NCTM) (2000), kemampuan penalaran matematis merupakan urutan kedua setelah kemampuan pemecahan masalah.

Ansjar dan Sembiring (2000) mengemukakan bahwa penalaran merupakan karakteristik utama matematika yang tidak dapat dipisahkan dari kegiatan mempelajari dan mengembangkan matematika atau menyelesaikan suatu masalah matematika. Kemampuan penalaran ini berguna bagi seseorang dalam proses membangun dan membandingkan gagasan-gagasan dari beragam situasi yang dihadapi, sehingga ia dapat mengambil keputusan yang tepat dalam menyelesaikan permasalahan hidupnya. Menurut Wahyudin (2008), penalaran menawarkan caracara yang tangguh untuk membangun dan mengekspresikan gagasan-gagasan tentang beragam fenomena yang luas.

Bertolak belakang dengan pentingnya kemampuan penalaran matematis, fakta di lapangan menunjukkan bahwa kemampuan penalaran matematis belumlah memuaskan. Salah satu hasil penelitian di Indonesia yang menunjukkan masih rendahnya kemampuan penalaran matematis di tingkat mahasiswa calon guru matematika dikemukakan oleh Armiati (2011). Menurut Armiati (2011), rendahnya kemampuan penalaran mahasiswa ini disebabkan oleh kegiatan perkuliahan yang kurang efektif, bahkan tidak jarang perkuliahan hanya berlangsung satu arah saja. Kegiatan perkuliahan yang berlangsung satu arah tentunya dapat menghambat bertumbuhkembangnya kemampuan berpikir tingkat tinggi di kalangan mahasiswa, antara lain kemampuan penalaran matematis.

Berdasarkan uraian di atas, maka perlu dilakukan inovasi dalam pengembangan (model) pembelajaran matematika yang dapat mengakomodasi dan mengembangkan kemampuan penalaran matematis bagi mahasiswa, khususnya mahasiswa calon guru matematika. Salah satu alternatif yang berpotensi dapat mengembangkan kemampuan berpikir mahasiswa adalah dengan menerapkan model pembelajaran reflektif (Reflective Learning).

Pembelajaran reflektif merupakan pembelajaran dengan melibatkan kegiatan berpikir reflektif pada prosesnya. Menurut Boud, et al (Sirajuddin, 2009; Kurnia, 2006) refleksi merupakan kegiatan intelektual dan afektif yang melibatkan mahasiswa dalam mengekplorasi pengalaman mereka untuk mencapai pemahaman dan apresiasi-apresiasi baru. Boud, Keogh \& Walker (Priyatni, Hamidah, dan Adi, 2017) menyatakan bahwa dengan pembelajaran reflektif mahasiswa harus memikirkan ulang tentang apa yang telah dikerjakan dan dipahaminya, sehingga dapat mengasah kemampuan berpikir kritis mahasiswa, dan mendorong mahasiswa untuk menuju pendekatan yang mendalam. Selain itu, pembelajaran reflektif terbukti dapat meningkatkan kemampuan penalaran matematis mahasiswa (Rohana, 2015a).

Selanjutnya, selain inovasi dalam model pembelajaran, pemanfaatan teknologi informasi dipandang sebagai suatu hal yang dapat membantu dalam mengembangkan kemampuan penalaran matematis mahasiswa. Pembelajaran reflektif membutuhkan 
waktu yang tidak terbatas pada jam kuliah (Rohana, 2015b). Oleh karena itu pembelajaran reflektif yang biasanya dilakukan hanya pada kelas tatap muka dengan waktu yang singkat dapat dilanjutkan di kelas virtual. Penerapan kelas virtual diidentifikasi berpotensi dalam mendukung proses pembelajaran reflektif (Herrington, et. al, 2000).

Kelas virtual dibuat dengan menggunakan bantuan aplikasi Moodle (Modular Object Orinted Dynamic Learning Environment). Moodle merupakan salah satu aplikasi dari konsep dan mekanisme belajar mengajar yang memanfaatkan teknologi informasi berbasis web, yang sering dikenal dengan konsep e-learning, dan telah banyak digunakan oleh orang di seluruh dunia khususnya universitas, sekolah dan juga para praktisi pengajar (Kurniawan, 2009). Menurut Psycharis, Chataloglidis, \& Kalogiannakis (Ningsih, 2015) Moodle memberikan kesempatan kepada dosen untuk mengontrol kegiatan mahasiswa di luar jam tatap muka dengan adanya informasi seperti jumlah kunjungan, jumlah waktu yang digunakan untuk menyelesaikan tugas, nilai, dan sebagainya.

Moodle menyediakan tempat untuk berbagai macam sumber belajar termasuk sumber multimedia seperti Flash dan Java applets (Godwins \& Jones, 2003). Selain itu, Moodle menciptakan lingkungan belajar yang nyaman bagi mahasiswa, mahasiswa dapat berinteraksi dan berkolaborasi sama seperti halnya proses pembelajaran di ruangan kelas (Dougiamas, 2011). Moodle memberikan fasilitas kepada mahasiswa untuk dapat belajar meskipun mereka tidak berada di ruangan kelas. Hal ini dirasa sangat sesuai untuk diterapkan di perguruan tinggi mengingat latar belakang mahasiswa yang banyak berasal dari luar kota.

Manfaat Moodle dalam pembelajaran matematika telah dikaji oleh banyak peneliti. Khairiree (2010) menyebutkan bahwa pembelajaran matematika dengan menggunakan bantuan Moodle dapat meningkatkan hasil belajar mahasiswa pada mata kuliah matematika bisnis. Selain itu, Moodle didentifikasi dapat melatih kemampuan pemecahan masalah peserta didik (Weng, et.al, 2012). Secara umum Moodle mempunyai efek yang positif dalam mendukung kelancaran proses pembelajaran matematika (Mersġnoğullari, et. al, 2014).

Penelitian ini bertujuan untuk mengetahui peningkatan kemampuan penalaran matematis mahasiswa melalui pembelajaran reflektif berbantuan aplikasi Moodle.

\section{METODE}

Penelitian ini merupakan penelitian deskriptif. Penelitian ini bertujuan untuk mengetahui bagaimana peningkatan kemampuan penalaran matematis mahasiswa semester III.B Program Studi Pendidikan Matematika Universitas PGRI Palembang melalui pembelajaran reflektif berbantuan aplikasi Moodle. Penelitian ini menggunakan desain one group pretest-postest design. Desain ini melibatkan satu kelompok eksperimen yang memperoleh perlakuan dengan model pembelajaran reflektif berbantuan aplikasi Moodle. Kelompok tersebut diberikan tes awal dan tes akhir. Subjek dalam penelitian ini adalah 33 orang mahasiswa semester III.B Program Studi Pendidikan Matematika Tahun Akademik 2017/2018 yang mengontrak mata kuliah Statistika Matematika. Kelas III.B terpilih sebagai subjek penelitian karena peneliti merupakan dosen pengasuh mata kuliah Statistika Matematika, sehingga tidak menimbulkan bias kepada mahasiswa yang diteliti. Data dikumpulkan melalui tes kemampuan awal matematika dan tes kemampuan penalaran matematis. Untuk mengetahui besarnya peningkatan kemampuan 
penalaran matematis mahasiswa dilakukan dengan rumus gain ternomalisasi (n-gain) dari Hake (1999).

\section{HASIL DAN PEMBAHASAN}

Kegiatan belajar mengajar dilaksanakan di kelas III.B dengan jumlah mahasiswa sebanyak 33 orang. Penelitian ini dilaksanakan dalam 7 kali pertemuan, yang terdiri dari 1 kali pertemuan pendahuluan, 1 kali pertemuan pelaksanaan tes awal, 4 kali pertemuan pelaksanaan pembelajaran dan 1 kali pertemuan untuk pelaksanaan tes akhir.

Pembelajaran reflektif berbantuan aplikasi Moodle diterapkan pada setiap kali pertemuan. Pembelajaran reflektif meliputi 5 langkah yaitu sebagai berikut: (1) Context, dosen menyajikan topik pembelajaran sebagai pengetahuan baru yang akan dibahas. (2) Experience, dosen memunculkan permasalahan baru berkaitan dengan topik yang akan dibahas dan disajikan dalam Lembar Diskusi. (3) Reflection, dosen mengarahkan mahasiswa dan kelompoknya untuk dapat mencari berbagai informasi yang mendukung penyelesaian masalah (mengumpulkan data-data pendukung), merumuskan letak dan batasan masalah, serta penyelesaian masalah yang mungkin. (4) Action, dosen memberikan kesempatan pada mahasiwa untuk mempresentasikan jawaban mereka dan sharing dalam diskusi kelas. (5) Evaluation, dosen melakukan evaluasi dengan meminta mahasiswa menjawab beberapa pertanyaan dan menulis jurnal reflektif. Aplikasi Moodle digunakan oleh mahasiswa dalam mengunduh dan menjawab Lembar Diskusi, mencari informasi dan pembuatan jurnal reflektif. Penjelasan tentang penggunaan aplikasi Moodle dilakukan pada pertemuan pendahuluan.

Tes KAM digunakan untuk mengelompokkan mahasiswa menurut kemampuan matematis yang dimiliki mahasiswa sebelum proses pembelajaran dalam penelitian ini dilakukan. Hasil perhitungan terhadap data KAM secara keseluruhan, diperoleh $\bar{x}=5,36$ dan $s=2,50$. Distribusi pengelompokan mahasiswa berdasarkan KAM disajikan pada Tabel 1.

Tabel 1. Distribusi mahasiswa berdasarkan KAM

\begin{tabular}{cc}
\hline Kelompok KAM & Jumlah \\
\hline Tinggi & 7 \\
Sedang & 23 \\
Rendah & 3 \\
\hline Jumlah & 33 \\
\hline
\end{tabular}

Pelaksanaan pembelajaran dilaksanakan setelah tes KAM. Contoh cuplikan tampilan aplikasi Moodle yang digunakan dalam pembelajaran disajikan dalam Gambar 1. Postes dilakukan setelah pembelajaran. Statistik deskriptif data postes kemampuan penalaran matematis mahasiswa selengkapnya disajikan pada Tabel 2. Pada Tabel 2. terlihat bahwa secara keseluruhan mahasiswa yang mendapatkan pembelajaran reflektif berbantuan aplikasi moodle menunjukkan adanya peningkatan kemampuan penalaran matematis. Hasil tersebut didukung oleh rerata postesnya yaitu sebesar 10,67. Peningkatan kemampuan penalaran matematis mahasiswa berdasarkan kelompok KAM (tinggi, sedang, rendah), dan 
keseluruhannya secara lebih jelas dapat dilihat dalam diagram batang pada Gambar 2 .

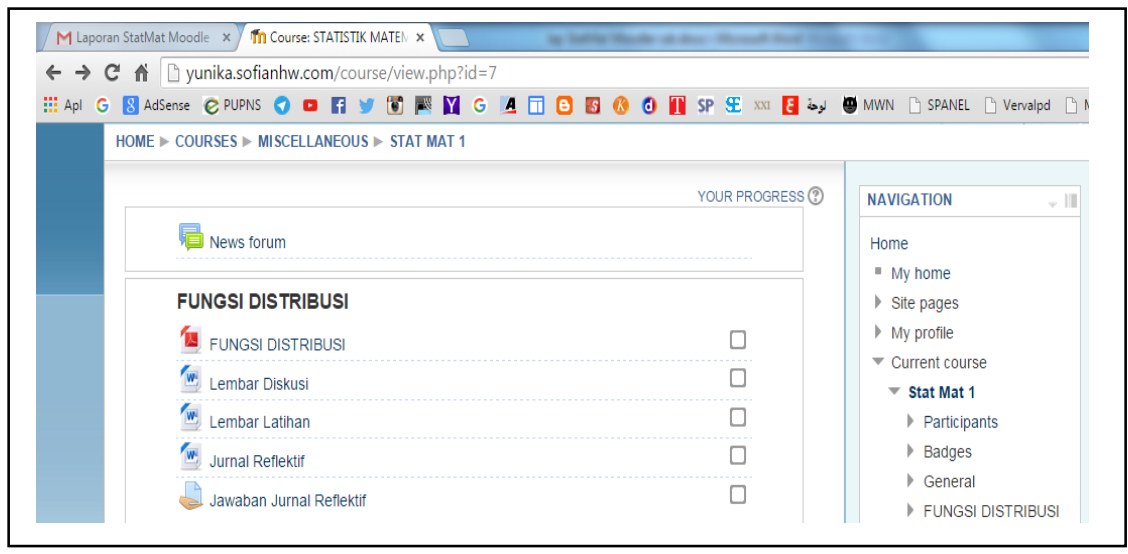

Gambar 1. Cuplikan tampilan aplikasi Moodle

Tabel 2. Statistik deskriptif kemampuan penalaran matematis mahasiswa

\begin{tabular}{lccccc}
\hline \multirow{2}{*}{ Kelompok KAM } & \multicolumn{5}{c}{ Pembelajaran Reflektif Berbantuan Moodle } \\
\cline { 2 - 6 } & $\mathrm{N}$ & Stat & Pretes & Postes & n-gain \\
\hline \multirow{2}{*}{ Keseluruhan } & \multirow{2}{*}{33} & $\bar{x}$ & 5,97 & 10,67 & 0,36 \\
& $S$ & 1,45 & 2,37 & 0,16 \\
\hline \multirow{2}{*}{ Tinggi } & \multirow{2}{*}{7} & $\overline{\boldsymbol{x}}$ & 6,00 & 11,86 & 0,43 \\
& & $S$ & 1,29 & 2,85 & 0,24 \\
\hline \multirow{2}{*}{ Sedang } & \multirow{2}{*}{23} & $\bar{x}$ & 5,87 & 9,30 & 0,26 \\
& & $S$ & 1,39 & 1,66 & 0,13 \\
\hline \multirow{2}{*}{ Rendah } & \multirow{2}{*}{3} & $\bar{x}$ & 5,33 & 7,00 & 0,12 \\
& & $S$ & 1,53 & 1,00 & 0,03 \\
\hline
\end{tabular}

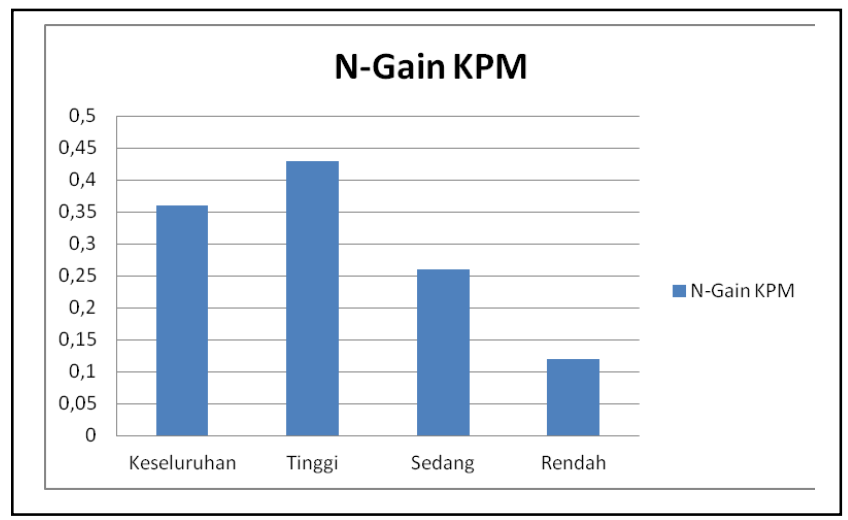

Gambar 2. Peningkatan kemampuan penalaran matematis mahasiswa

Berdasarkan Gambar 2 tampak bahwa berdasarkan kelompok KAM, peningkatan tertinggi berada pada mahasiswa dengan kelompok KAM tinggi dengan n-gain sebesar 0,43 dan termasuk dalam kategori sedang. Hal ini menunjukkan 
bahwa mahasiswa pada kelompok KAM tinggi mendapatkan dampak yang cukup besar dari pembelajaran reflektif berbantuan aplikasi Moodle ini.

Analisis hasil pekerjaan mahasiswa dalam menyelesaikan tes kemampuan penalaran matematis dilihat dari lima aspek, yaitu kemampuan: (1) menginterpretasikan suatu permasalahan berdasarkan konsep matematika terkait; (2) mengamati hubungan sebab akibat dari informasi yang diberikan dan dapat menyelesaikan masalah; (3) menarik analogi dari permasalahan yang serupa; (4) menganalisis permasalahan yang diberikan; dan (5) membuat keputusan dan menguji kebenaran rumus/jawaban yang diperoleh. Hasil pekerjaan mahasiswa pada setiap aspek dapat dilihat pada Tabel 3.

Berdasarkan Tabel 3 terlihat bahwa setelah mendapatkan pembelajaran reflektif berbantuan aplikasi Moodle, KPM mahasiswa mengalami peningkatan. Peningkatan itu terjadi pada setiap aspek yang diukur maupun secara keseluruhan

Tabel 3. Nilai rata-rata aspek kemampuan penalaran matematis

\begin{tabular}{|c|c|c|c|c|}
\hline \multirow{2}{*}{ No } & \multirow[t]{2}{*}{ Aspek yang diukur } & \multicolumn{3}{|c|}{$\begin{array}{c}\text { Pembelajaran Reflektif Berbantuan } \\
\text { Moodle }\end{array}$} \\
\hline & & Pretes & Postes & n-gain \\
\hline 1 & $\begin{array}{lr}\text { Menginterpretasikan } & \text { suatu } \\
\text { permasalahan berdasarkan } & \text { konsep } \\
\text { matematika terkait. }(\mathrm{SMI}=4) & \end{array}$ & $\begin{array}{c}1,55 \\
(38,64 \%)\end{array}$ & $\begin{array}{c}1,91 \\
(47,73 \%)\end{array}$ & 0,15 \\
\hline 2 & $\begin{array}{l}\text { Mengamati hubungan sebab akibat } \\
\text { dari informasi yang diberikan dan } \\
\text { dapat menyelesaikan masalah. } \\
(\mathrm{SMI}=3)\end{array}$ & $\begin{array}{c}0,76 \\
(25,25 \%)\end{array}$ & $\begin{array}{c}1,00 \\
(33,3 \%)\end{array}$ & 0,11 \\
\hline 3 & $\begin{array}{l}\text { Menarik analogi dari permasalahan } \\
\text { yang serupa. }(\mathrm{SMI}=4)\end{array}$ & $\begin{array}{c}1,85 \\
(46,21 \%)\end{array}$ & $\begin{array}{c}3,03 \\
(75,8 \%)\end{array}$ & 0,55 \\
\hline 4 & $\begin{array}{l}\text { Menganalisis permasalahan yang } \\
\text { diberikan. (SMI= 4) }\end{array}$ & $\begin{array}{c}0,97 \\
(24,24 \%)\end{array}$ & $\begin{array}{c}3,55 \\
(88,6 \%)\end{array}$ & 0,85 \\
\hline 5 & $\begin{array}{l}\text { Membuat keputusan dan menguji } \\
\text { kebenaran rumus/jawaban } \text { yang } \\
\text { diperoleh }(\mathrm{SMI}=4)\end{array}$ & $\begin{array}{c}0,85 \\
(21,21 \%)\end{array}$ & $\begin{array}{c}1,27 \\
(31,82 \%)\end{array}$ & 0,13 \\
\hline & Keseluruhan (SMI=19) & $\begin{array}{c}6,97 \\
(31,42 \%)\end{array}$ & $\begin{array}{c}10,67 \\
(56,14 \%)\end{array}$ & 0,36 \\
\hline
\end{tabular}

Apabila ditinjau dari kelima aspek penalaran matematis yang diukur, diketahui peningkatan KPM terbesar mahasiswa yang mendapatkan pembelajaran reflektif berbantuan aplikasi Moodle terjadi pada aspek keempat, yaitu kemampuan menganalisis. Sedangkan peningkatan terendah terjadi pada aspek kedua, yaitu kemampuan mengamati hubungan sebab akibat dari informasi yang diberikan dan dapat menyelesaikan masalah.

Contoh peningkatan untuk aspek keempat yaitu pada saat pretes mahasiswa Mahasiswa belum memahami tentang konsep distribusi normal, sehingga hanya menuliskan apa yang diketahui dari permasalahan. Pada tahap ini, mahasiswa telah menunjukkan langkah analisis tapi penyelesaiannya belum benar. Jawaban pretes mahasiswa pada aspek ini dapat dilihat pada Gambar 3. 


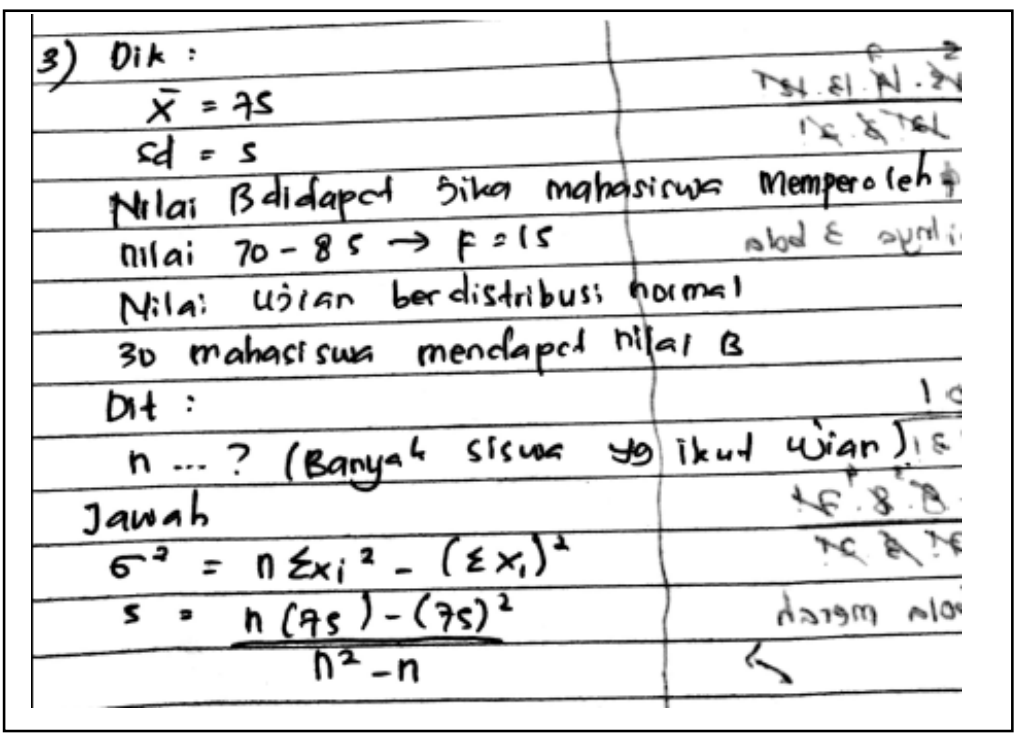

Gambar 3. Jawaban mahasiswa pada saat pretes

Setelah dilakukan pembelajaran reflektif berbantuan aplikasi Moodle mahasiswa mampu memahami distribusi normal, analisis yg diberikan mahasiswa sudah tepat sehinga dapat menyelesaikan masalah dengan benar. Jawaban mahasiswa pada saat postes dapat dilihat pada Gambar 4.

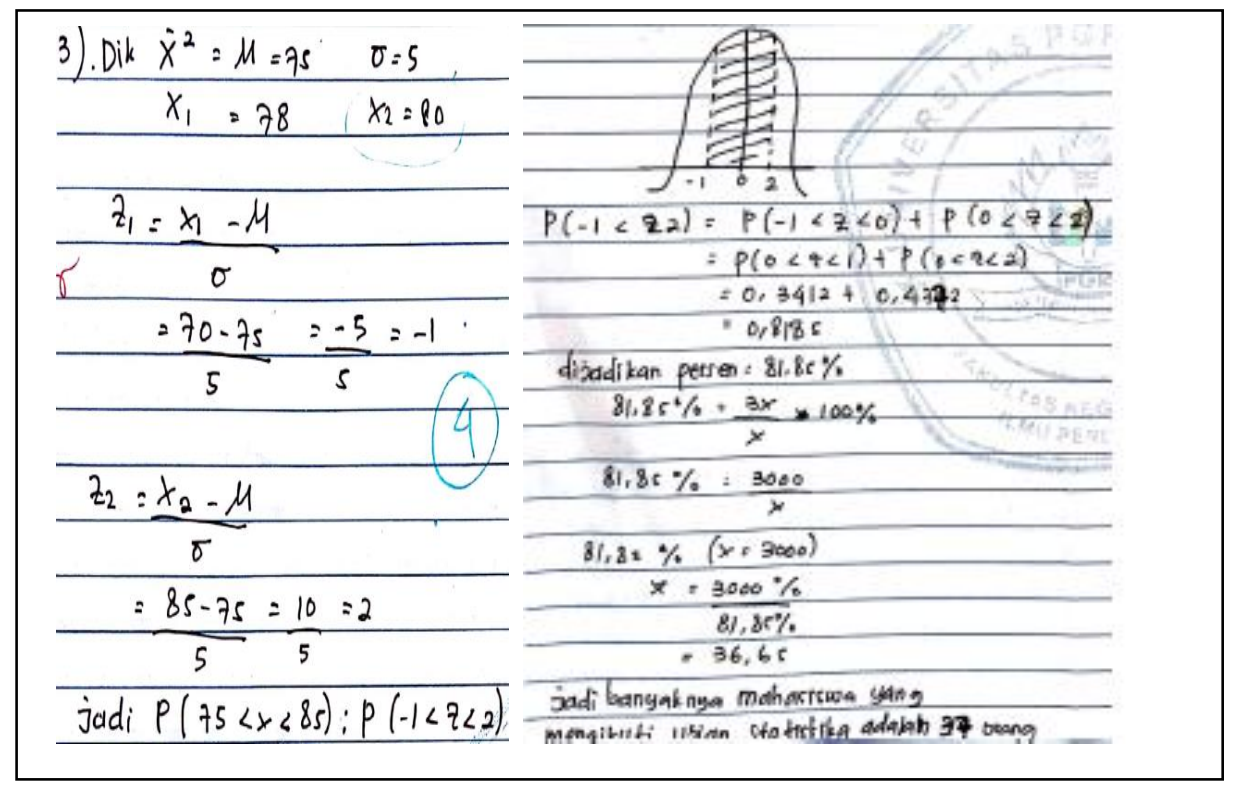

Gambar 4. Jawaban mahasiswa pada saat postes

Peningkatan kemampuan penalaran matematis ini dapat terjadi karena pada pembelajaran reflektif, mahasiswa dilatih dan dibiasakan berpikir matematis melalui soal-soal berbasis masalah, serta pertanyaan-pertanyaan refleksi dari dosen maupun bahan ajar. Dengan demikian, mahasiswa akan terampil dalam mengumpulkan informasi yang relevan, menganalisis informasi, dan menyadari betapa pentingnya menguji kembali hasil yang telah diperolehnya. Pada akhirnya mahasiswa akan memiliki kemampuan mengambil keputusan yang merupakan bagian dari indikator 
penalaran matematis. Sebagaimana ditegaskan oleh Conney (Hudojo, 1988) bahwa mengajarkan penyelesaian masalah kepada peserta didik memungkinkan mereka menjadi lebih analitik di dalam mengambil keputusan di dalam hidupnya.

Pada pembelajaran reflektif mahasiswa diberi kesempatan untuk berperan aktif dalam proses pembelajaran, khususnya saat melakukan diskusi (diskusi kelompok dan diskusi kelas). Mahasiswa mengorganisasi ide-ide dan pengetahuan yang mereka miliki terkait dengan masalah, selain itu mahasiswa dapat mengajukan pertanyaan atau isu-isu sekitar masalah. Selanjutnya mahasiswa diberi kesempatan untuk menyatakan apa yang mereka pahami dan tidak pahami. Saat diskusi kelompok berlangsung, dosen berkeliling kelas memperhatikan diskusi yang terjadi. Apabila diperlukan, dosen sebagai fasilitator dapat memberikan petunjuk atau scaffolding kepada mahasiswa untuk membuat keterkaitan antara konsep-konsep dan prosedurprosedur matematis. Scaffolding yang diberikan dosen berupa pertanyaan-pertanyaan reflektif yang bersifat membantu mahasiswa ketika mengalami kesulitan dalam menyelesaikan masalah. Hal ini bersesuaian dengan pernyataan Baig dan Anjun (2006) bahwa suasana kelas yang bersahabat sangat mendukung peningkatan kemampuan penalaran, karena peserta didik akan berpendapat, mengajukan pertanyaan dan menggambarkan pemikirannya tanpa ragu-ragu.

Penulisan jurnal reflektif dilakukan mahasiswa pada akhir pembelajaran. Mahasiswa mengunggah jurnal reflektif melalui menu yang disediakan pada aplikasi Moodle. Contoh jurnal reflektif yang ditulis oleh mahasiswa dapat dilihat pada Gambar 5.

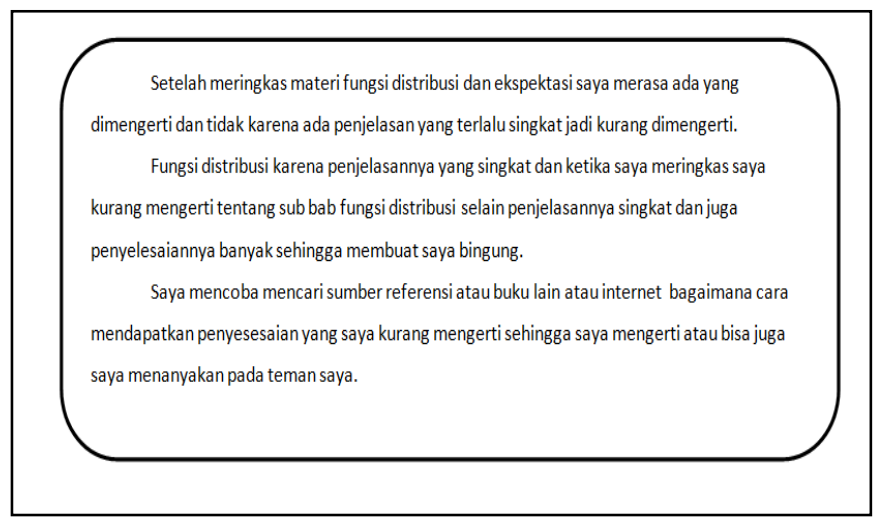

Gambar 5. Contoh jurnal reflektif mahasiswa

Penulisan jurnal reflektif diakhir pembelajaran yang dilakukan oleh mahasiswa pada aplikasi Moodle, mampu merekam hubungan-hubungan dan makna-makna yang diperoleh mahasiswa saat proses pembelajaran, sehingga membantu mahasiswa menyatukan proses refleksi yang telah dilakukan. Hal yang senada diungkapkan oleh Coughlan (2007) bahwa jurnal reflektif (reflective journal) digunakan peserta didik untuk mencatat kemajuan studinya yang membantu mereka menemukan strategi belajarnya sekaligus sebagai evaluasi kinerja mereka. Lebih lanjut Coughlan (2007) menyatakan bahwa berpikir dan menulis merupakan proses yang tidak dapat dipisahkan, menulis secara reflektif berarti secara tidak langsung menuntun mahasiswa untuk berpikir tentang proses berpikirnya sendiri atau dikenal dengan istilah 'metakognisi'. Sebagaimana yang dikemukakan Sternberg (1999) bahwa aktivitas metakognisi merupakan bagian dari aspek penalaran matematis. 


\section{SIMPULAN DAN SARAN}

Berdasarkan hasil penelitian dapat disimpulkan bahwa peningkatan kemampuan penalaran matematis mahasiswa melalui pembelajaran reflektif berbantuan aplikasi Moodle tergolong dalam kategori sedang. Berdasarkan kesimpulan tersebut, maka disarankan kepada dosen atau tenaga pengajar lainnya untuk dapat menerapkan model pembelajaran reflektif berbantuan aplikasi Moodle dalam upaya meningkatkan kemampuan penalaran matematis mahasiswa.

\section{UCAPAN TERIMA KASIH}

Penelitian ini disponsori DIPA Universitas PGRI Palembang. Untuk itu peneliti mengucapkan terima kasih kepada Rektor Universitas PGRI Palembang, Kepala LPPKMK, Dekan FKIP, Ketua Jurusan dan Ketua Program Studi Pendidikan Matematika Universitas PGRI Palembang.

\section{DAFTAR PUSTAKA}

Ansjar, M. dan Sembiring. 2000. Hakikat Pembelajaran MIPA dan Kiat Pembelajaran Matematika di Perguruan Tinggi. Jakarta: Dirjen Dikti Depdiknas.

Armiati. 2011. Peningkatan Kemampuan Penalaran Matematis, Komunikasi Matematis dan Kecerdasan Emosional Mahasiswa Melalui Pembelajaran Berbasis Masalah. Disertasi tidak dipublikasikan. Bandung : Universitas Pendidikan Indonesia.

Baig, S. and Anjun H. 2006. Learning Mathematical Rules With Reasoning. Eurasia Journal of Mathematics, Science and Technology Education, Vol. 2(2) : 15-39.

Coughlan, A. 2007. Reflective Learning: Keeping a Reflective Learning Journal. [Online]. Tersedia :

https://www.dcu.ie/sites/default/files/students/Reflectivelearning.pdf. [16 Desember 2016].

Dougiamas, M. 2011. Using Workshop Moodle 2.2. [Online]. Tersedia : http://docs.moodle.org/22/en/Using_Workshop. [ 13 Desember 2016].

Godwin-Jones, B. 2003. Tools for Distance Education: Towards Convergence and Integration. Language Learning \& Technology, Vol. 7(3) : 18-22.

Hake, R. 1999. Analizing Change/gain Scores. [Online]. Tersedia : http://www.physics.indiana.edu/-sdi/AnalyzingChange-Gain.pdf.html. [ 13 Desember 2016].

Herrington, T., Herrington, J., Oliver, R., and Omari, A. 2000. A Web-based Resource Providing Reflective Online Support for Preservice Mathematics Teachers on School Practice. Contemporary Issues in Technology and Teacher Education, Vol. 1(2) : 117-140.

Hudojo, H. 1988. Mengajar Belajar Matematika. Jakarta: Dirjen Dikti-Depdikbud.

Khairiree, K. 2010. A Study of Constructivist In Mathematics In Virtual Class With Moodle and The Geometer's Sketchpad. [Online]. Tersedia : http://atcm.mathandtech.org/EP2011/invited_papers/3272011_19339.pdf. [10 November 2016].

Kurnia, I. 2006. Pengembangan Model Pembelajaran Untuk Meningkatkan Kemampuan Reflektif Mahasiswa S1-PGSD Pada Mata Kuliah Penelitian 
Tindakan Kelas. Disertasi tidak dipublikasikan. Bandung : Universitas Pendidikan Indonesia.

Kurniawan, R. 2009. Membangun Media Ajar Online Untuk Orang Awam. Palembang : Maxicom.

Mersġnoğullari, O., Yildirim, O.G., Özmüg, P., Duymaz, S.H., Tepe, T., and Ilic, U. 2014. The Geometer's Sketchpad Education on Moddle. International Journal of Engineering Science and Innovative Technology (IJESIT), Vol. 3(6) : 337-346.

National Council of Teachers of Mathematics (NCTM). 2000. Principles and Standards for School Mathematics. Reston, VA: NCTM.

Ningsih, Y. L. 2015. Pengembangan Bahan Ajar Turunan Berdasarkan Teori Apos Untuk Pembelajaran Blended Learning di Perguruan Tinggi. Tesis tidak diterbitkan. Palembang: Universitas Sriwijaya.

Rohana. 2015a. The Enhancement of Student's Teacher Mathematical Reasoning Ability Through Reflective Learning. Journal of Education and Practice, Vol. 6(20) : 108-114.

---------. 2015b. Peningkatan Kemampuan Penalaran dan Komunikasi Matematis Serta Karakter Mahasiswa Calon Guru Melalui Pembelajaran Reflektif. Disertasi tidak dipublikasikan. Bandung : Universitas Pendidikan Indonesia.

Sirajuddin. 2009. Model Pembelajaran Reflektif: Suatu Model Belajar Berbasis Pengalaman. Didaktika Jurnal Kependidikan, Vol. 4(2) : 189-200.

Sternberg, R. J. 1999. The Nature of Mathematical Reasoning. In L.V. Stiff, and F.R. Curcio (Eds.), Developing Mathematical Reasoning in Grades k-12 (pp. 3744). Reston, Virginia: NCTM.

Suryadi, D. 2012. Membangun Budaya Baru dalam Berpikir Matematika. Bandung: Rizqi Press.

Priyatni, E.T., Hamidah, S.C., dan Adi, P. 2017. Pembelajaran Reflektif: Model Pembelajaran Reflektif yang Responsif Teknologi. Tangerang: Tira Smart.

Wahyudin. 2008. Pembelajaran dan Model-model Pembelajaran. Bandung: Universitas Pendidikan Indonesia.

Weng, T.S., Shu, M.H., Lin, J.Y., \& Yang, D.C. 2012. Using Mathematical Subjects to Study Self-Test for Enhancement The Detection of Learning Effectiveness. International Journal of e-Education, e-Business, e-Management and $e$ Learning, Vol. 2(3) : 206-210. 